\title{
Role of environmental factors on phytoplankton bloom initiation under landfast sea ice in Resolute Passage, Canada
}

\author{
C. J. Mundy ${ }^{1,2, *}$, Michel Gosselin ${ }^{2}$, Yves Gratton ${ }^{3}$, Kristina Brown ${ }^{4}$, \\ Virginie Galindo ${ }^{5}$, Karley Campbell ${ }^{1}$, Maurice Levasseur ${ }^{5}$, David Barber ${ }^{1}$, \\ Tim Papakyriakou ${ }^{1}$, Simon Bélanger ${ }^{6}$
}

\footnotetext{
${ }^{1}$ Centre for Earth Observation Science (CEOS), University of Manitoba, Winnipeg, Manitoba R3T 2N2, Canada ${ }^{2}$ Institut des sciences de la mer (ISMER), Université du Québec à Rimouski, Rimouski, Québec G5L 3A1, Canada ${ }^{3}$ Institut National de la Recherche Scientifique — Eau, Terre et Environnement, Université du Québec, Québec, Québec G1P 4S5, Canada
}

${ }^{4}$ Earth, Ocean and Atmospheric Sciences, University of British Columbia, Vancouver, British Columbia V6T 1Z4, Canada ${ }^{5}$ Département de biologie, Université Laval, Québec, Québec G1V 0A6, Canada

${ }^{6}$ Département de biologie, chimie et géographie, Université du Québec à Rimouski, Rimouski, Québec G5L 3A1, Canada

\begin{abstract}
It has been common practice in scientific studies to assume negligible phytoplankton production when the ocean is ice-covered, due to the strong light attenuation properties of snow, sea ice, and ice algae. Recent observations of massive under-ice blooms in the Arctic challenge this concept and call for a re-evaluation of light conditions prevailing under ice during the melt period. Using hydrographic data collected under landfast ice cover in Resolute Passage, Nunavut, Canada between 9 May and 21 June 2010, we documented the exponential growth phase of a substantial under-ice phytoplankton bloom. Numerous factors appeared to influence bloom initiation: (1) transmitted light increased with the onset of snowmelt and termination of the ice algal bloom $_{i}(2)$ initial phytoplankton growth resulted in the accumulation of biomass below the developing surface melt layer where nutrient concentrations were high and turbulent mixing was relatively low; and (3) melt pond formation rapidly increased light transmission, while spring-tidal energy helped form a surface mixed layer influenced by ice melt - both were believed to influence the final rapid increase in phytoplankton growth. By the end of the study, nitrate+nitrite was depleted in the upper $10 \mathrm{~m}$ of the water column and the under-ice bloom had accumulated $508 \mathrm{mg}$

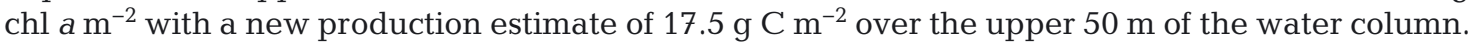
The timing of bloom initiation with melt onset suggests a strong link to climate change where sea ice is both thinning and melting earlier, the implication being an earlier and more ubiquitous phytoplankton bloom in Arctic ice-covered regions.
\end{abstract}

KEY WORDS: Under-ice bloom $\cdot$ Phytoplankton $\cdot$ Arctic $\cdot$ Sea ice melt $\cdot$ Transmitted PAR Resale or republication not permitted without written consent of the publisher

\section{INTRODUCTION}

Phytoplankton growth under sea ice has been sporadically documented over the last $50 \mathrm{yr}$ in the Arctic (e.g. English 1961, Fukuchi et al. 1989, Michel et al. 1993, Strass \& Nöthig 1996, Fortier et al. 2002, Arrigo et al. 2012). However, it remains common practice to assume negligible water column production when the ocean is ice-covered, due to the strong light attenuation properties of snow, sea ice, and ice algae. Recently, Mundy et al. (2009) showed that significant primary production can take place under sea ice dur- 
ing the spring-summer transition, when sea ice melt rapidly increases light transmission and enhances surface stratification of the water column.

In fact, under-ice phytoplankton blooms can rival open water blooms as demonstrated in Arrigo et al. (2012). In the Canadian high Arctic, under-ice water column integrated chlorophyll a (chl a) concentrations have been documented to exceed $450 \mathrm{mg} \mathrm{m}^{-2}$ (Fortier et al. 2002). It was suggested that the central Canadian Arctic archipelago could represent a region where under-ice phytoplankton blooms have been a regular, yet under-documented occurrence due to several important factors (Mundy et al. 2009). The shallow and narrow waterways of the archipelago act to mix nutrient-rich waters into the surface layer (Michel et al. 2006). The narrow waterways also result in extensive landfast sea ice formation that locks ice in place long into the melt period, permitting it to reach very advanced stages of ice melt prior to break-up. Furthermore, the waterways and landfast ice limit intrusions of large, thick multiyear ice floes from the central Arctic ice pack, resulting in a predominant first-year ice (FYI) cover towards central and southern regions of the Archipelago (Melling 2002).

It is important to consider that FYI has become the dominant ice type in the Arctic at the expense of a rapidly disappearing multiyear ice cover (Comiso et al. 2008). Among other distinguishing factors, FYI is generally less thick with a thinner snow cover (due to timing of formation) and during the melt season, tends to have greater areal melt pond coverage (due to less topographic relief) in comparison to multiyear ice (Polashenski et al. 2012). Subsequently, considerably more light transmits through FYI than through multiyear ice (Nicolaus et al. 2012). With enhanced water-column light absorption associated with the ice-albedo feedback, a decrease in seasonal sea ice thermodynamic growth also is expected (Perovich et al. 2011). All of these factors play a significant role on the amount of light transmitted to the underlying water column. Furthermore, water temperatures under the sea ice in the western Arctic are usually close to freezing, which would reduce top-down influences on under-ice phytoplankton bloom development (Sherr et al. 2009). Therefore, Mundy et al. (2009) suggested that the importance of under-ice phytoplankton blooms in the Arctic marine ecosystem could increase with the thinning ice cover. If this suggestion proves true, under-ice phytoplankton blooms could represent a major, yet challenging to monitor, response of the ecosystem to climate change. As part of a time-series landfast ice study in the central Canadian Arctic archipelago called the Arctic - Ice Covered Ecosystem (Arctic-ICE) study, we identified a set of environmental conditions that led to the development of an under-ice phytoplankton bloom. Our study took place from 9 May to 21 June 2010, with a focus on the timing of key environmental factors that initiated the bloom.

\section{MATERIALS AND METHODS}

\section{Data collection}

The Arctic-ICE 2010 main field study took place on landfast ice in Resolute Passage $\left(74^{\circ} 42.6^{\prime} \mathrm{N}\right.$, 95⒖0' W; $141 \mathrm{~m}$ water depth), near Resolute Bay, Nunavut, Canada (Fig. 1). A meteorological station was installed within $500 \mathrm{~m}$ of our main site at which air temperature (3.9 m height; Vasailla HMP45C212 sensor), shortwave surface albedo (1.3 m height; Kipp \& Zonen ${ }^{\mathrm{TM}}$ CNR1 sensor), and incident photosynthetically available radiation (PAR; 1.3 m height; Kipp \& Zonen ${ }^{\mathrm{TM}}$ PAR-Lite sensor) were monitored during the study. Two separate tethers, each with

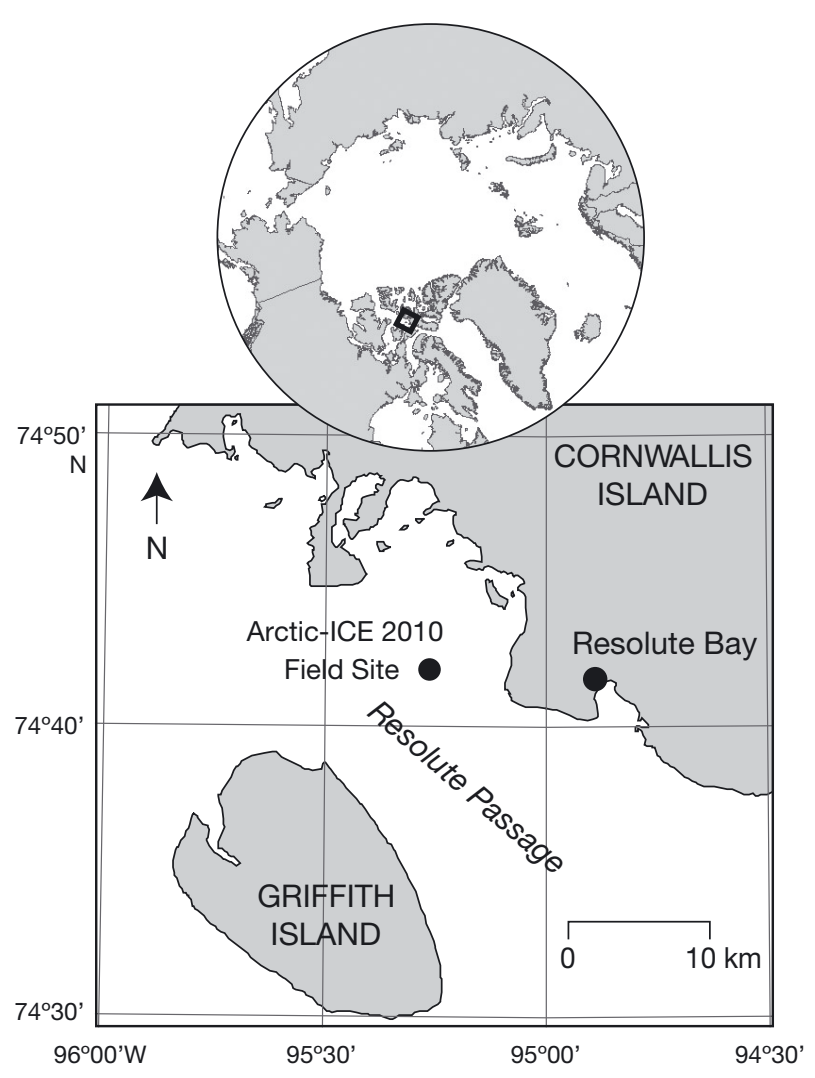

Fig. 1. Arctic-ICE 2010 study site located in Resolute Passage, Nunavut, Canada, at $74^{\circ} 42.6^{\prime} \mathrm{N}$ and $95^{\circ} 15.0^{\prime} \mathrm{W}$ over a $141 \mathrm{~m}$ water depth 
scalar PAR sensors (ALEC MKV-L) mounted at 2, 5, $7.5,10$, and $20 \mathrm{~m}$ water depths, were moored to the ice under high $(>30 \mathrm{~cm})$ and low $(<12 \mathrm{~cm})$ snow depth sites, respectively, to monitor transmitted PAR. The tethers were installed approximately $500 \mathrm{~m}$ from the main meteorological station through $4 \mathrm{~cm}$ diameter ice auger holes while air temperatures were still well below freezing. A range is presented in percent transmittance estimates in an effort to compare the underwater scalar versus incident cosine irradiance measurements. The range was derived by multiplying the under-ice scalar measurements by a downwelling irradiance average cosine of 0.5 (diffuse light field; minimum estimate) and 1.0 (downward directed light field; maximum estimate). Furthermore, to simplify, we assumed negligible upward irradiance in the under-ice water column. To measure currents, a $614 \mathrm{kHz}$ Acoustic Doppler Current Profiler (ADCP; RD Instruments Workhorse Sentinel 600) was mounted at the ice bottom looking downward following Marsden et al. (1994). Due to logistical problems, ADCP data only cover the periods of 10 to 23 May and 27 May to 9 June 2010. As tides are the main influence on local currents, we used current velocities centered at a $3 \mathrm{~m}$ water depth predicted by harmonic analysis over the entire study period (Pawlowicz et al. 2002). The harmonic analysis correlated well with the actual observations $\left(\mathrm{r}^{2}=0.50, \mathrm{n}=644\right)$, but provided consistently lower velocities, and were therefore considered conservative estimates. Hydrographic profiles from 2 to $130 \mathrm{~m}$ using a SBE-19 plus CTD sensor (Seabird Electronics) equipped with an in vivo chl a fluorometer (Wet Labs ECO-FLRT) were collected at an approximate daily interval through a $1 \times 1 \mathrm{~m}$ hole covered with a heated enclosure. Sensor casts started at $2 \mathrm{~m}$ to minimize the influence of the ice access hole on the profiles (e.g. pooling of melt water within the hole). A quadratic polynomial was used to calibrate fluorometer data against extracted chl a measurements (Parsons et al. 1984) from discrete water column samples $\left(r^{2}=0.98, n=83\right)$. Fluorescence of the extracted pigments was measured before and after acidification with $5 \% \mathrm{HCl}$ using a 10-005R Turner Designs fluorometer. Chl a concentrations were then calculated using the equation described by Holm-Hansen et al. (1965).

Using 5 l Niskin bottles, water column samples were collected immediately following the morning's CTD cast at 2, 5, 10, 25, 50, and 130 m every 3 to $4 \mathrm{~d}$ throughout the study. Nitrate+nitrite, silicic acid and phosphate concentrations were measured on water column samples using a Bran-Luebbe 3 autoanalyzer (adapted from Grasshoff et al. 1999). Particulate or- ganic carbon (POC) and nitrogen (PON) were measured on selected water subsamples filtered through precombusted $\left(450^{\circ} \mathrm{C}\right)$ Whatman $\mathrm{GF} / \mathrm{F}$ filters dried at $60^{\circ} \mathrm{C}$ for $24 \mathrm{~h}$ and analyzed using a Costech ECS 4010 CHN analyzer. Furthermore, selected subsamples were taken for cell identification and enumeration, preserved with acidic Lugol's solution (Parsons et al. 1984) and stored in the dark at $4^{\circ} \mathrm{C}$ until analysis. Cells $>2 \mu \mathrm{m}$ were identified to the lowest possible taxonomic rank using inverted microscopy according to Lund et al. (1958).

On the day after water column sampling, sea ice core samples (bottom $10 \mathrm{~cm}$ ) were collected using a $9 \mathrm{~cm}$ core barrel (Kovacs Mark II). Ice cores were sampled at a distributed sampling site under 3 snow depths when present: low $(<10 \mathrm{~cm})$, medium $(10-$ $20 \mathrm{~cm})$ and high $(>20 \mathrm{~cm})$ classes. The distributed sampling site was located $<500 \mathrm{~m}$ from the PAR tether site and $<1000 \mathrm{~m}$ from the meteorological station. We attempted to monitor the snow classes as melt commenced, which resulted in a decrease in snow depths with the low class represented by melt ponds over the final 2 sampling days. For each class, 2 to 3 ice cores were pooled together in isothermal 7.51 containers and diluted using $0.2 \mu \mathrm{m}$-filtered seawater to minimize osmotic shock of the microbial community while melting (Garrison \& Buck 1986). Samples were melted in the dark over a 12 to $24 \mathrm{~h}$ period. Subsamples from ice melt were taken for determination of chl $a, \mathrm{POC}$, and cell identification and enumeration.

\section{RESULTS}

\section{Light transmission}

Prior to 6 June, air temperatures were predominately less than $0^{\circ} \mathrm{C}$, and surface albedo slowly decreased over the first half of the study from 0.9 to 0.8 (Fig. 2a,b). Following 6 June, air temperatures mostly remained above $0^{\circ} \mathrm{C}$. Furthermore, between 6 and 14 June, surface albedo decreased from 0.8 to 0.7 as the snow cover melt rate increased, then proceeded to exponentially decrease after 14 June as a melt pond formed under the radiation tower. Hereinafter, 6 and 14 June are described as snow melt and melt pond onsets, respectively. Daily averaged incident PAR seasonally increased with slight variations associated with cloud cover (Fig. 2c). In particular, a system with thick cloud cover and light snow precipitation occurred over 10 and 11 June, causing a decrease in incident PAR over this period. Daily aver- 

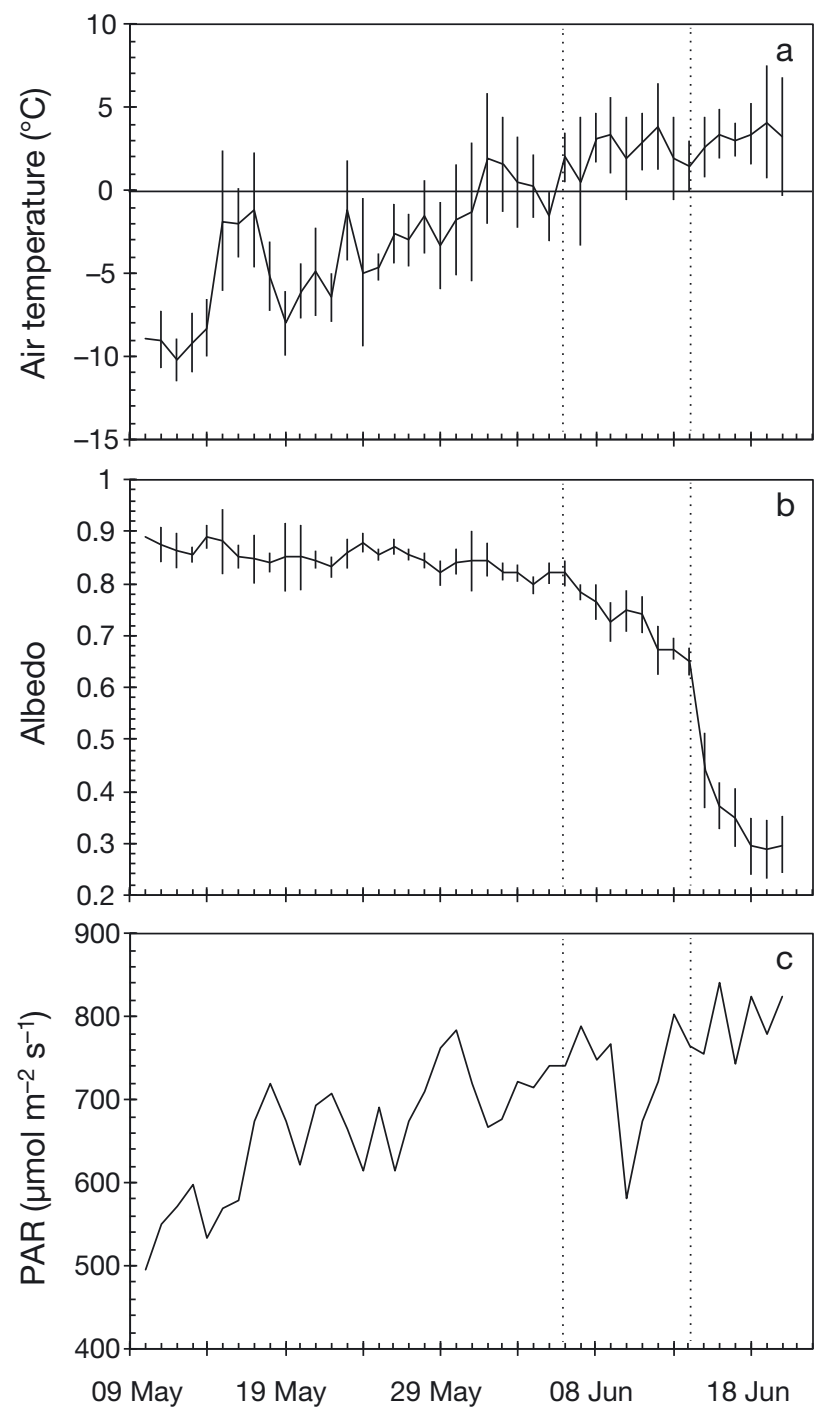

Fig. 2. Time series of daily averaged (a) air temperature, (b) surface shortwave albedo, and (c) incident downwelling photosynthetically available radiation (PAR) monitored at the automated meteorological station installed near the ice camp. Vertical bars are standard deviations of the daily averages and vertical dotted lines show snow melt and melt pond onsets, respectively

aged transmitted PAR closely followed incident PAR with a slow increase prior to 6 June, particularly under the low snow cover (Fig. 3b,c). As snowmelt increased after 6 June, transmitted PAR rapidly increased, with 0.4 to $0.7 \%$ incident PAR reaching a $20 \mathrm{~m}$ depth by 14 June. After the formation of surface melt ponds, transmitted PAR at $2 \mathrm{~m}$ depth reached a maximum of 253 (16 to $32 \%$ incident PAR) and $152 \mu \mathrm{mol}$ photons $\mathrm{m}^{-2} \mathrm{~s}^{-1}$ (10 to $20 \%$ incident PAR) by the end of the study under the low and high snow depth sites, respectively. Using light attenuation measured between the 2, 5, 7.5, and $10 \mathrm{~m}$ sensors, we
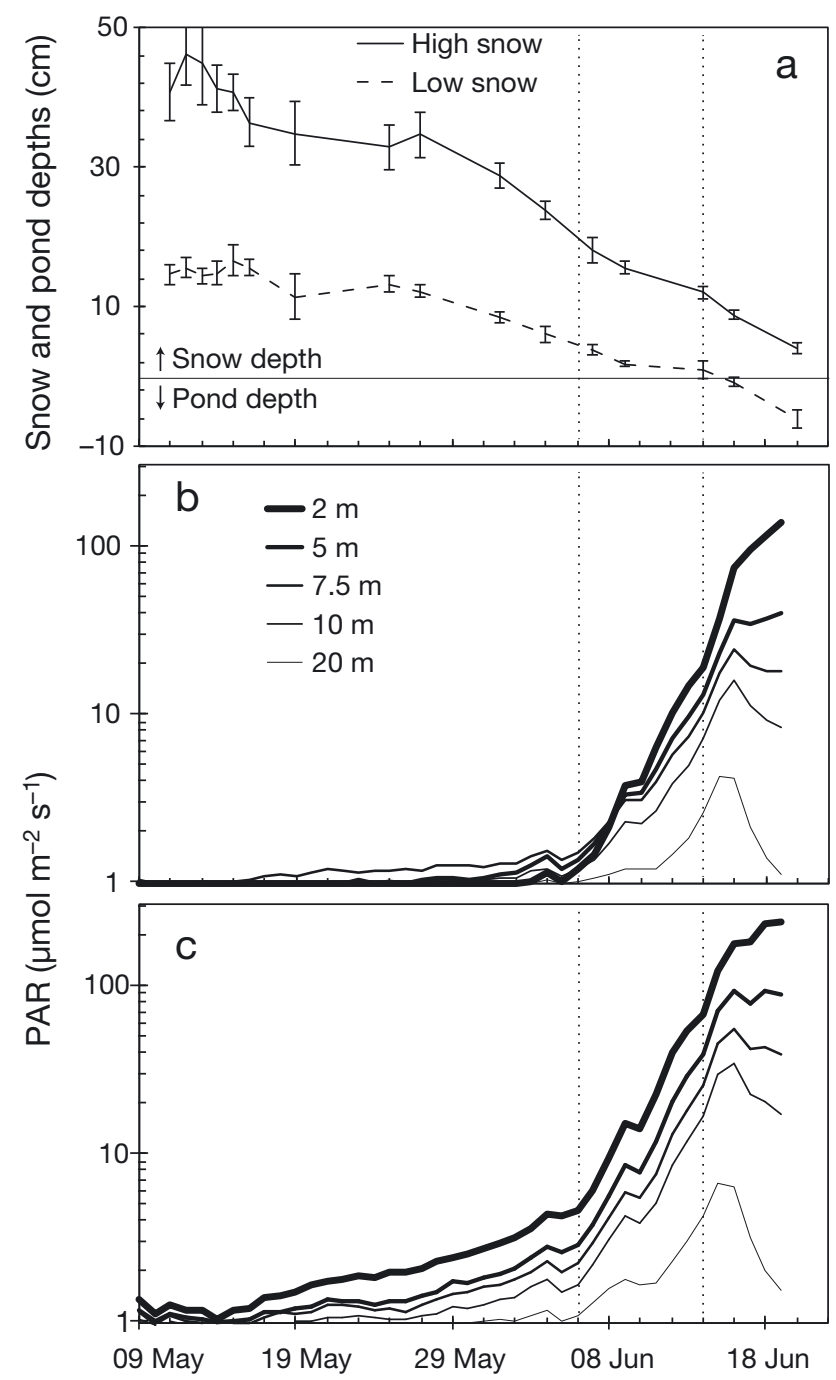

Fig. 3. Daily measured (average with standard deviation bars) (a) snow and melt pond depths at the high and low snow sites where transmitted photosynthetically available radiation (PAR) was monitored at specified depths along icemoored tethers. Daily averaged transmitted PAR (plotted on a log scale) is presented for the (b) high and (c) low snow depth site tethers, respectively. Vertical dotted lines are snow melt and melt pond onsets, respectively

extrapolated the percent of incident PAR transmitted to the ice bottom to be 21 to $42 \%$ and 11 to $22 \%$ for the low and high snow depth sites, respectively. These percent transmitted irradiances fit within the range of transmitted PAR to the ice bottom reported in Ehn et al. (2011) under similar surface cover. However, water column attenuation increased during this period due to phytoplankton accumulation (see below), resulting in a decrease in transmitted PAR to depth. Interestingly, PAR under the high snow cover site was higher at $7.5 \mathrm{~m}$ than at shallower depths before 8 June. This apparent inversion in surface 
transmitted PAR attenuation was likely a function of horizontal light propagation under the variable snow and ice surface (Ehn et al. 2011).

\section{Timing of primary producers}

At the start of the study, ice algal chl a was highest (45 $\mathrm{mg} \mathrm{m}^{-2}$ ) under the low snow class but decreased to an average of $6 \mathrm{mg} \mathrm{m}^{-2}$ between 30 May through the end of the study (Fig. 4a,c). Under the medium snow class, ice algal chl a accumulated during the first portion of the study to $46 \mathrm{mg} \mathrm{m}^{-2}$, then rapidly decreased after 31 May. Ice algal chl a under the high snow class followed a similar pattern to that of the

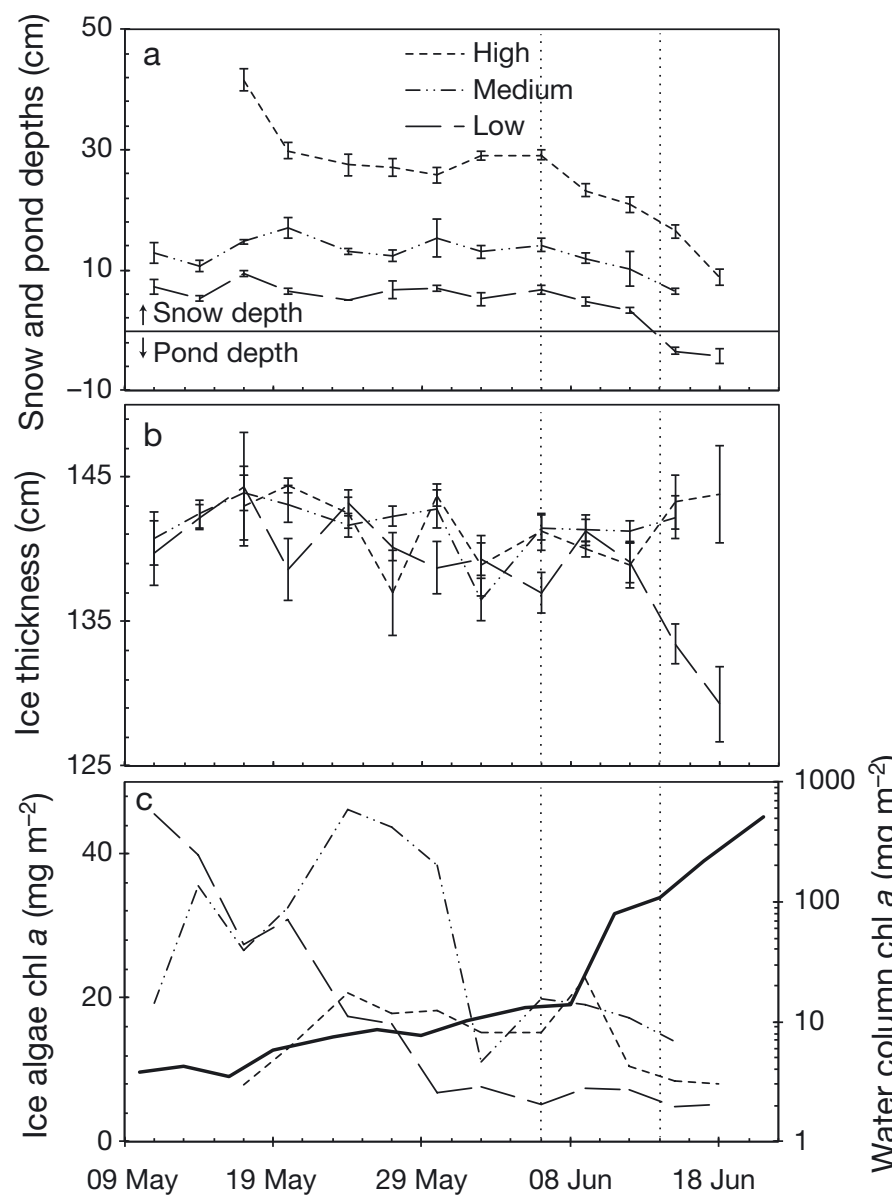

Fig. 4. Average (with standard deviation bars where appropriate) of (a) snow and melt pond depth, (b) ice thickness, and (c) bottom ice algae chlorophyll a ( $\mathrm{chl}$ a) concentration measured at high, medium, and low snow depth class distributed sampling sites (dashed lines). Included in (c) is a plot of water column chl a concentration integrated over the upper $50 \mathrm{~m}$ (right axis with log scale; solid line) from discrete water samples collected at 2, 5, 10, 25, and $50 \mathrm{~m}$ approximately every third day. Vertical dotted lines are snow melt and melt pond onsets, respectively medium but remained relatively low throughout the study. These observations agree with previous studies where ice algae under low snow covers are lost first from the sea ice during the spring-summer transition, likely associated with ablation of the ice algal habitat (Mundy et al. 2005, Juhl \& Krembs 2010) and possibly photoinhibition (Juhl \& Krembs 2010). In contrast, ice algae under the medium and high snow classes were probably light limited and thermally insulated from the atmosphere (Mundy et al. 2005) to start, then as air temperature and transmitted light levels increased, a loss of algae from the ice occurred. By 2 June, ice algal chl a was consistently less than $20 \mathrm{mg} \mathrm{m}^{-2}$ under all the snow classes. Interestingly, following 30 May, a minimal ice algal chl a $\left(\sim 6 \mathrm{mg} \mathrm{m}^{-2}\right)$ remained as a visible film on the bottom of the ice cores under the low snow class, even though the ice was rapidly ablating with the formation of surface melt ponds. We surmise that the ice algae were actively growing, balancing a loss associated with ice ablation during this period.

Discrete samples of chl a integrated over the upper $50 \mathrm{~m}$ of the water column showed a slow but steady exponential increase up to $14 \mathrm{mg} \mathrm{m}^{-2}$ prior to 8 June (Fig. 4c, solid line). During this early period, ice algae were consistently sloughing from the low and, later, medium and high snow cover sites. This sloughing can help explain the slight increase in water column chl a. An alternative explanation could be slow accumulation of light limited in situ phytoplankton production. For example, Lovejoy et al. (2007) observed a slow exponential increase in chl a and cell concentrations in the under-ice water column before and during an ice algal bloom in the Beaufort Sea, which was suggested to be associated with in situ production by picoplankton. Between 8 and 11 June, we observed a rapid rise in water column integrated chl $a$, followed by a shallow increase that lasted until 14 June, then a rapid exponential increase to a maximum of $508 \mathrm{mg} \mathrm{m}^{-2}$ by the end of the study period. This maximum closely matched that previously observed in Resolute Passage (Fortier et al. 2002). From a sample taken on 19 June, the under-ice phytoplankton community $>2 \mu \mathrm{m}$ was found to be numerically dominated by the centric diatoms Chaetoceros spp. and Thalassiosira spp., which accounted for $68 \%$ and $7.5 \%$ of the total autotrophs, respectively. In contrast, a sample of the ice algae under the medium snow depth collected on 24 May (i.e. prior to the major sloughing event) revealed that $75 \%$ of the community were pennate diatoms, with $40 \%$ and $18 \%$ Nitzschia frigida and Navicula pelagica, respectively. Therefore, it was clear that the under-ice 
phytoplankton bloom was distinct, and accumulated at least an order of magnitude more chl a than the ice algae while the local region was still ice-covered. It is also significant to note that the under-ice bloom followed $\sim 1$ wk after the majority of ice algae had sloughed from the ice bottom. From their relationship with chl a concentration presented in Ehn \& Mundy (2013), bottom ice scalar attenuation coefficients were estimated to be 39.8 and $13.6 \mathrm{~m}^{-1}$ for the observed maximum and minimum bottom ice chl $a$ concentrations of 46 and $5 \mathrm{mg} \mathrm{m}^{-2}$, respectively. Therefore, applying Lambert-Beer's law (Gordon 1989), the decrease in bottom ice chl a observed in our study corresponded to a $50 \%$ increase in transmitted irradiance. Thus, the loss of ice algae also contributed significantly to the seasonal increase in underice transmitted irradiance.

\section{Under-ice bloom dynamics}

There was a periodicity in water column profiles of temperature and salinity from the hydrocast data (Fig. 5a,b). For example, the $-1.6^{\circ} \mathrm{C}$ and 32.5 salinity isolines shoaled at a frequency that closely corresponded to timing of changes in current velocities (Fig. 6), which are driven predominately by the spring-neap tidal cycle in Resolute Passage (Marsden et al. 1994). On 14 June, salinity started to decrease slightly at the $2 \mathrm{~m}$ water depth, coupled with an increase in stratification in the upper 2 to $3 \mathrm{~m}$ (Brunt-Väisälä frequency $\left(N^{2}\right)=1.85 \times 10^{-3} \mathrm{~s}^{-2}$ from maximum values of $\leq 0.16 \times 10^{-3} \mathrm{~s}^{-2}$ prior to 14 June; data not shown). This decrease in salinity and increase in stratification was likely associated with the commencement of melt water collecting at the undersurface of the sea ice. Following 16 June, salinities rapidly decreased in the surface water column (Fig. 5b). This rapid decrease corresponded with peak current velocities associated with the spring tide, suggesting that tidal energy had acted to deepen the surface stratified layer by mixing the melt layer with the underlying water column. Following Mann \& Lazier (1991), the squared current velocity showed that mixing forces were up to 18 times stronger during the maximum peak of predicted tidal currents on 16 June relative to the minimum of the daily maximum predicted current velocities reached on 6 June. By 21 June, a strong salinity gradient created a pycnocline that extended to a depth of $47 \mathrm{~m}$ (Fig. 7a).

From 8 to 11 June, a clearly defined increase in chl a occurred with peak concentrations around a

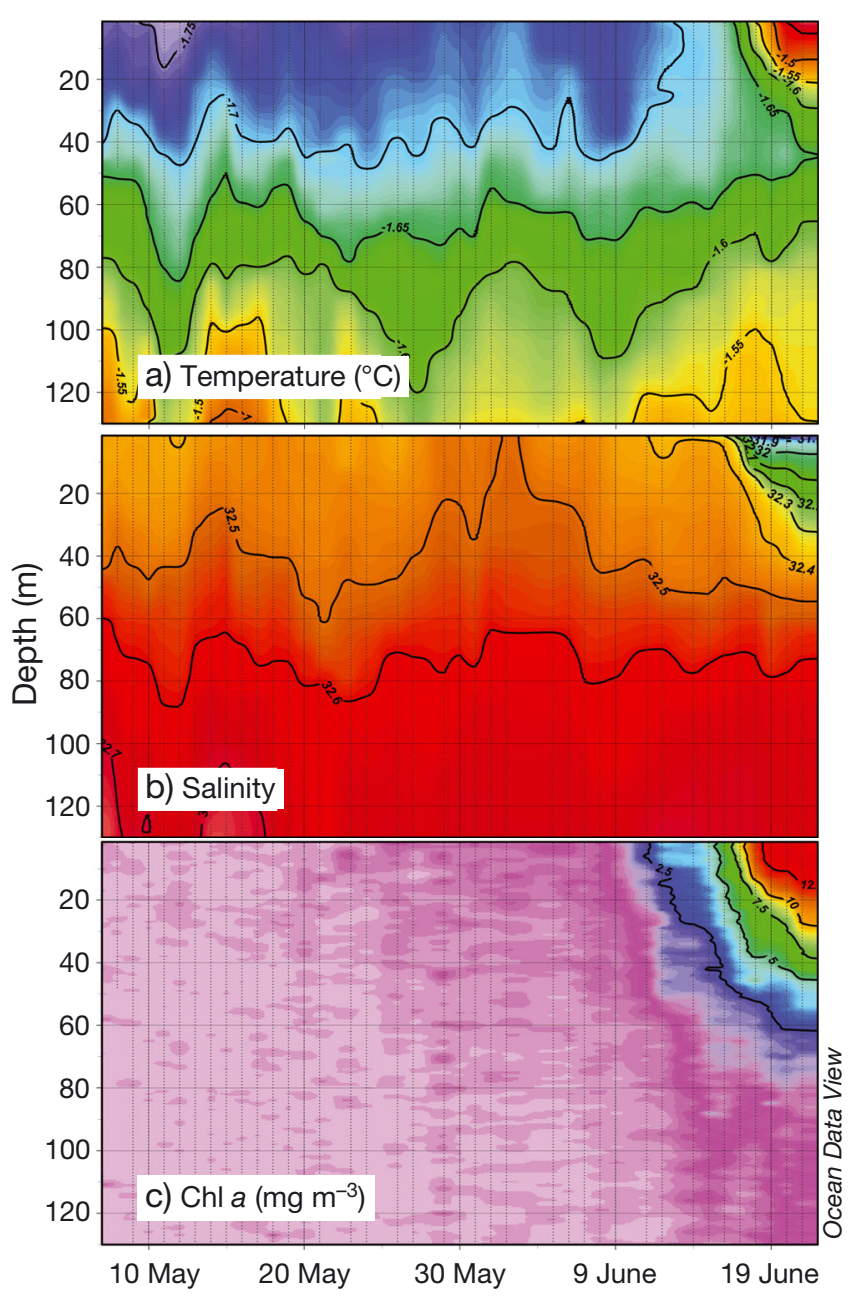

Fig. 5. Interpolated time series of (a) water column temperature $\left({ }^{\circ} \mathrm{C}\right)$, (b) salinity, and (c) chlorophyll a concentration via in vivo fluorescence $\left(\mathrm{mg} \mathrm{m}^{-3}\right)$. Data from 67 hydrocasts (vertical dotted lines) were interpolated and plotted using Ocean DataView v. 3.3.1 (Schlitzer 2006)

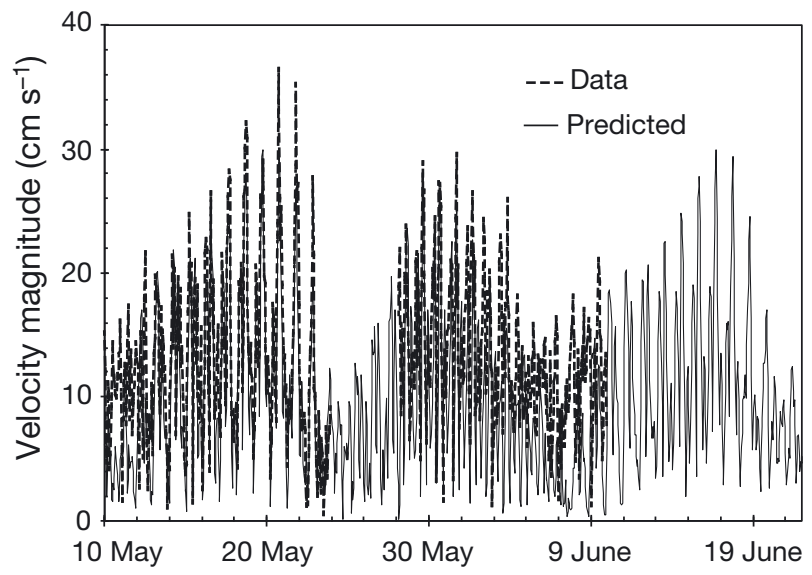

Fig. 6. Absolute current velocities measured with a downlooking $614 \mathrm{kHz}$ ADCP (2 m bin centered at a $3 \mathrm{~m}$ water depth) and predicted using harmonic analysis 

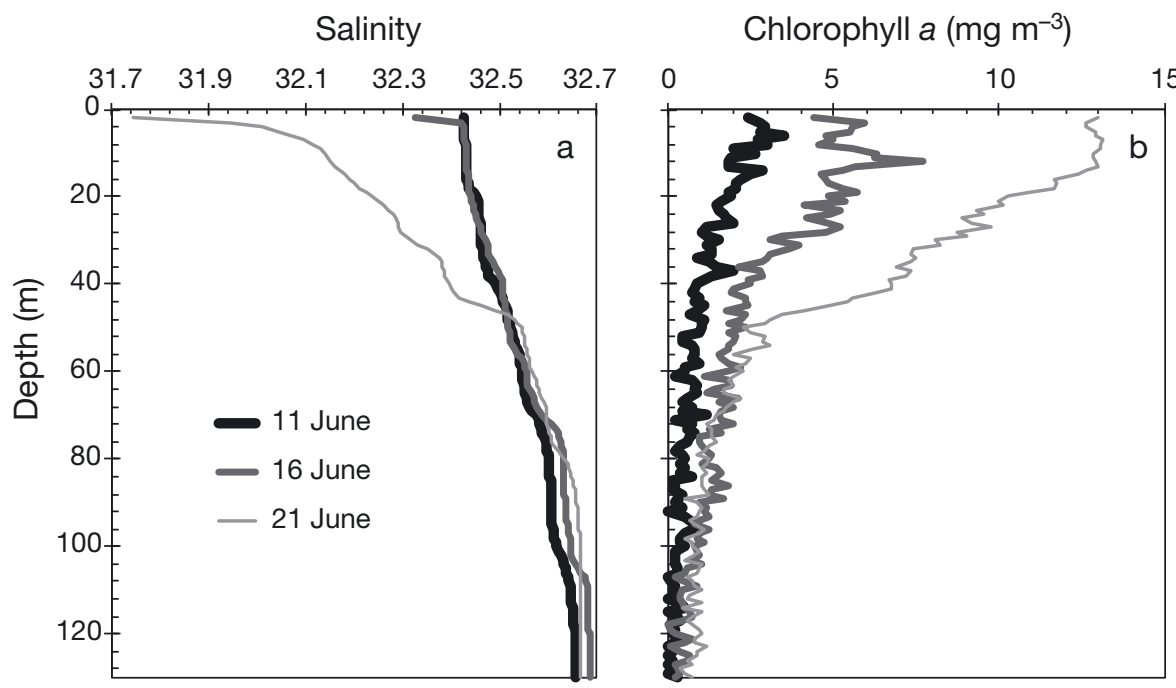

Fig. 7. Water column profiles of (a) salinity and (b) chlorophyll a (via in vivo fluorescence) on 11, 16, and 21 June

$6 \mathrm{~m}$ water depth and a long decreasing tail reaching depths of more than $100 \mathrm{~m}$ (Figs. 5c \& 7b). As the surface water column was not strongly stratified during this period, the under-ice phytoplankton were likely produced within the euphotic zone, then settled down in the water column. We note that the chl $a$ peak at $6 \mathrm{~m}$ occurred below any ice melt water influence. Ice melt water is expected to be nutrient deplete due to segregation and brine drainage processes during ice growth. Unfortunately, only 1 low salinity surface water sample (salinity of 6.9) was collected during our study. In accordance with a nutrient deplete ice melt assumption, silicic acid and phosphate concentrations fell below a dilution curve crossing through the origin, but nitrate+nitrite concentrations fell well above (data not shown). Cota et al. (1990) noted that ice algae may store intracellular pools of nitrate, evidenced by elevated concentrations in the sea ice. These intracellular pools could be released as cells encounter osmotic stress during ice melt. Future work on this topic is warranted.

Water column chl a only slightly increased between 11 and 14 June but then increased exponentially following 14 June to the end of the study period (Fig. 4c). This growth increase matched with the timing of melt pond formation on the ice surface and deepening of the surface mixed layer that was influenced by low salinity ice melt.

Water column nutrient concentrations were divided by their salinity, averaged over the upper $10 \mathrm{~m}$ of the water column, then multiplied (standardized) to an averaged salinity of 32.4 to examine the temporal development of the bloom through nutrient drawdown (Fig. 8). Prior to 6 June, standardized nitrate+ nitrite, silicic acid, and phosphate concentrations were relatively stable, averaging $7.2,14.7$, and $1.2 \mu \mathrm{mol} \mathrm{l} \mathrm{l}^{-1}$, respectively. These concentrations fall along the lower range previously reported for the region (Cota et al. 1990, Michel et al. 2006). Following 6 June, standardized nutrient concentrations were drawdown with molar uptake ratios for silicic acid:nitrate+nitrite of $1.7\left(r^{2}=0.98, \mathrm{n}=5\right)$ and nitrate+ nitrite:phosphate of $10.3\left(r^{2}=0.99, n=5\right)$. Our silicic acid:nitrate+nitrite uptake ratio was slightly less than that presented for the western Canadian Arctic (1.8 to 1.9 ) associated with a diatom dominated subsurface chlorophyll maximum (Tremblay et al. 2008). Tremblay et al. (2008) suggested that a high optimal silicon requirement for the dominant diatoms and growth under low irradiance at the subsurface chlorophyll maximum best explained the higher uptake ratios observed in the western Canadian Arctic. Both explanations fit the under-ice bloom observed in our study.

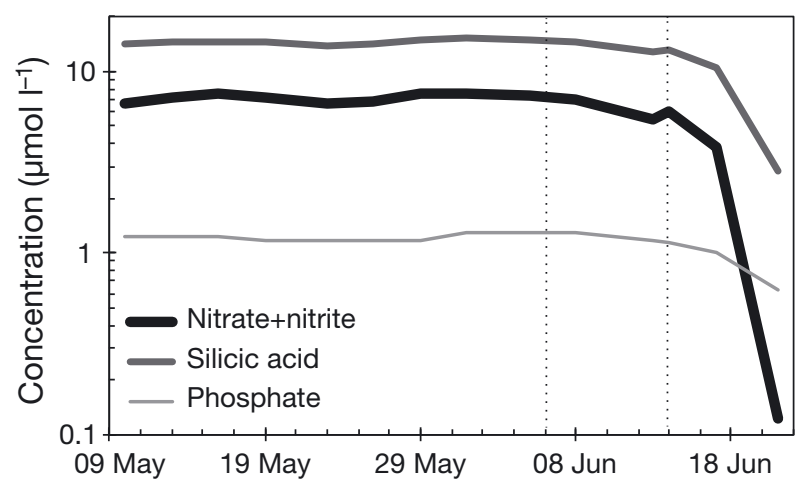

Fig. 8. Time series of nitrate+nitrite, silicic acid, and phosphate concentrations averaged over the upper $10 \mathrm{~m}$ water column and standardized to an average salinity of 32.4 
Prior to 6 June, nitrate+nitrite was well correlated with salinity $([$ nitrate+nitrite $]=8.60 \times$ salinity -272 ; $\left.\mathrm{r}^{2}=0.84, \mathrm{n}=63\right)$, similar to that observed by Cota et al. (1990) for the same region. By the end of the study period, nitrate+nitrite was depleted over the upper $10 \mathrm{~m}$ to less than $0.2 \mu \mathrm{mol} \mathrm{l}^{-1}$, whereas silicic acid and phosphate averaged 2.8 and $0.6 \mu \mathrm{mol} \mathrm{l^{-1 }}$, respectively. Using a conservative assumption that ice melt had an end point of 0 salinity and 0 nitrate+nitrite concentration, we constructed a dilution curve up to the lower data bounds of the abovementioned relationship. N-uptake was then calculated as the difference between the dilution curve and regression line with observations made on 21 June. N-uptake was integrated over the upper $50 \mathrm{~m}$ of the water column, then, following Smith et al. (1991), converted to a new production estimate using a measured POC: PON molar ratio of 6.7 . The resultant estimate was $17.5 \mathrm{~g} \mathrm{C} \mathrm{m}^{-2}$ for the bloom period 6 to 21 June, which corresponded to a daily average rate of $1.1 \mathrm{~g} \mathrm{C} \mathrm{m}^{-2}$ $\mathrm{d}^{-1}$. This daily average rate was close to the rate estimated during an ice-edge upwelling bloom in the Canadian Beaufort Sea (Mundy et al. 2009). Furthermore, a specific accumulation rate of $0.24 \mathrm{~d}^{-1}$ was obtained by fitting an exponential curve to the time series of integrated $(50 \mathrm{~m}) \mathrm{chl}$ a data between 5 and 21 June $\left(r^{2}=0.95, n=6\right)$. From this, a net particulate accumulation rate of $1.9 \mathrm{~g} \mathrm{C} \mathrm{m}^{-2} \mathrm{~d}^{-1}$ was estimated by multiplying the specific rate by the average chl $a$ over the period and converted to POC using a measured POC:chl a ratio of $50(\mathrm{~g}: \mathrm{g})$.

A current analysis on the $2 \mathrm{~m}$ resolution (3 to $27 \mathrm{~m}$ ) ADCP data was undertaken to examine the potential influence of advected biomass into the region from adjacent open waters. Averaged currents over the entire dataset moved in a northwest direction (along Resolute Passage) and increased approximately linearly from $<1 \mathrm{~cm} \mathrm{~s}^{-1}$ at $3 \mathrm{~m}^{\text {to }} 2.1 \mathrm{~cm} \mathrm{~s}^{-1}$ at $27 \mathrm{~m}$. These currents were comparable to those presented in Marsden et al. (1994), but in an opposite direction. We note that the lower current velocities are difficult to separate from instrument noise where a minimum random error of the order $1 \mathrm{~cm} \mathrm{~s}^{-1}$ (we averaged 60 one-minute ensembles) was associated with the ADCP. As our sampling station was approximately $25 \mathrm{~km}$ from the ice-edge in Barrow Strait, the above mean currents imply that water from the adjacent ice-free region would have transited for $29 \mathrm{~d}$ at $3 \mathrm{~m}$, and $14 \mathrm{~d}$ at $27 \mathrm{~m}$ before reaching our station. Sinking rates of diatom cells and chains have been found to range around $1 \mathrm{~m} \mathrm{~d}^{-1}$ (ca. 0.6 to $1.2 \mathrm{~m} \mathrm{~d}^{-1}$ ) during initial bloom phases (Riebesell 1989). At this sinking rate, a phytoplankton bloom would be vertically off- set by 14 to $29 \mathrm{~m}$ by the time cells were advected under our station. As the under-ice phytoplankton bloom first accumulated at $6 \mathrm{~m}$ and peak water column biomass was consistently observed above $12 \mathrm{~m}$ (Fig. 7b), we suggest that the majority of the biomass observed in our study was produced under the ice cover. Ocean color data from the Medium Resolution Imaging Spectrometer (MERIS) sensor at full resolution $(330 \mathrm{~m})$ were obtained (see the Supplement at www.int-res.com/articles/suppl/m497p039_supp.pdf) from the Ocean Biology \& Biogeochemistry Program (http://oceancolor.gsfc.nasa.gov/). Satellite-derived chl a concentration along the ice-edge remained low $\left(<0.5 \mathrm{mg} \mathrm{m}^{-3}\right)$ in the vicinity of the study site until the end of June. Although satellite-derived chl a concentration in presence of sea ice could be underestimated (Bélanger et al. 2007), these results suggest that the phytoplankton did not develop in the nearby open water during our study. By the end of June, however, high chl a concentrations ( $>2 \mathrm{mg} \mathrm{m}^{-3}$ and up to $10 \mathrm{mg} \mathrm{m}^{-3}$ ) appeared within Barrow Strait. These satellite data showed that the bloom in open water occurred at the same time or later as the underice bloom observed at our study site and, therefore, provided further evidence that our observations were of in situ under-ice production given the transit distance presented earlier.

\section{DISCUSSION}

Timing and initiation of the under-ice phytoplankton bloom in our case study can be divided into a series of stages and events:

Firstly, the majority of ice algae had sloughed from the sea ice at least $1 \mathrm{wk}$ prior to the commencement of the under-ice phytoplankton bloom. This sloughing demarcated the end of the ice algal bloom, and was important as high algal biomass in the bottom ice can attenuate similar levels of light as a deep $(>20 \mathrm{~cm}$ ) snow cover (Mundy et al. 2007). Although the early integrated chl a increase in the water column may have been associated with the sloughing ice algae, these algae apparently did not directly seed the under-ice phytoplankton bloom, as the dominant diatom composition of the 2 communities were distinct.

Secondly, snow melt onset rapidly decreased surface albedo, resulting in an exponential increase in transmitted irradiance that deepened the euphotic zone to at least $20 \mathrm{~m}$ prior to the formation of surface melt ponds. It was during this stage that the phytoplankton bloom started to develop. Interestingly, ac- 
cumulation of surface chl a occurred before any significant surface mixed layer developed in the water column. Recently, Taylor \& Ferrari (2011) showed through modeling and satellite observations that phytoplankton blooms in the North Atlantic could be initiated as a response to weakened turbulent convection associated with a decrease in the air-sea heat flux during the winter to spring transition. This weakened turbulent mixing was proposed as an alternative condition to the critical depth hypothesis that is applicable only for consistent mixing regimes (Sverdrup 1953). With respect to our dataset, both brine rejection during ice formation and tidal currents can increase turbulent mixing of the upper water column. The under-ice bloom in our study was initiated after melt onset (little to no brine rejection) and during neap-tide, and therefore during a period of weakened turbulent mixing. Due to the reduced shear, we speculate that the under-ice phytoplankton were able to grow near the surface, shade-acclimated to the low but ample light conditions. However, due to a lack of surface stratification $\left(N^{2} \leq 0.16 \times 10^{-3} \mathrm{~s}^{-2}\right)$, this initial phytoplankton growth appeared to be associated with rapid sinking of cells, inferred from the long decreasing tail of chl a down to depths $>100 \mathrm{~m}$. Similar observations have been made for under-ice phytoplankton blooms in this region (Apollonio \& Matrai 2011). A slight leveling in the chl a accumulation rate at the end of this stage coincided with a light snow precipitation event that occurred over 10 to 11 June, which caused incident and transmitted PAR to decrease slightly, decreasing the euphotic zone depth. Furthermore, increasing tidal currents toward the end of this period could have enhanced turbulent mixing, thus decreasing residence time of phytoplankton in the euphotic zone.

Thirdly, phytoplankton production accelerated following the formation of surface melt ponds. Melt pond formation further increased transmitted irradiance, but as phytoplankton biomass increased in the upper layers, water column light attenuation rapidly increased. The provision of ice melt water and tidal mixing with seawater during this period resulted in a strongly stratified surface mixed layer that also likely influenced the increased phytoplankton accumulation rate after 14 June.

The data presented in this paper clearly show the development of a phytoplankton bloom below landfast sea ice cover in Resolute Passage at the center of the Canadian Arctic archipelago. During our study, phytoplankton had accumulated an order of magnitude more chl $a$ in the water column than was observed in the ice cover during the ice algal bloom.
This finding, combined with previous observations of significant under-ice phytoplankton accumulation in the same vicinity (Fortier et al. 2002), supports the earlier hypothesis (Mundy et al. 2009) that under-ice phytoplankton blooms are likely a regular, but largely neglected occurrence in the Canadian Arctic archipelago, and perhaps across the Arctic. In particular, the accumulation of phytoplankton biomass below the ice cover in the Chukchi Sea reported in Arrigo et al. (2012) demonstrated the potential widespread importance of these blooms. Their occurrence may also shed new light on ice-edge blooms (e.g. Sakshaug \& Skjoldal 1989, Mundy et al. 2009, Perrette et al. 2011). In particular, accumulated underice phytoplankton biomass could act to seed ice-edge blooms as the edge recedes in summer (Strass \& Nöthig 1996) and perhaps during upwelling events.

From a historical dataset collected during 1956 and 1961 to 1963, Apollonio \& Matrai (2011) concluded that phytoplankton in the Canadian Arctic rapidly developed under intact melting sea ice, but about 2 to $3 \mathrm{wk}$ later than observed in our study. Indeed, Michel et al. (2006) reported the region's phytoplankton bloom to peak late July-early August in a $10 \mathrm{yr}$ dataset spanning 1983 to 1993. Although the maximum integrated $\mathrm{chl} a$ in our study closely matched the maximum observed from the 10 yr dataset compiled by Michel et al. (2006), it reached this value at least 1 mo prior, leading to the conclusion that our data lie on the early side of reported phytoplankton blooms for the region. This difference in timing is consistent with recent work on the timing of landfast ice breakup and formation that shows breakup in the archipelago has advanced by about the same period (Galley et al. 2012).

Derived from the passive microwave satellite data record spanning 1979 to 2005, Stroeve et al. (2006) showed that in response to a warming climate, ice melt onset in the Western Arctic has been occurring earlier at a significant rate of 4 to $5 \mathrm{~d}_{\text {decade }}{ }^{-1}$. The relationship between the start of the under-ice phytoplankton bloom and snowmelt onset links timing of local phytoplankton production to regional warming. Our observations on the early occurrence of maximum phytoplankton production could be indicative of a major shift in the timing of local phytoplankton production in the central Canadian Arctic. This point could be critical as timing may be the single most important element affecting the ice-covered ecosystem through its influence on the transfer of organic carbon to the ice, pelagic, or benthic food webs (Leu et al. 2011). Furthermore, a currently thinning ice cover could lead to a more ubiquitous occurrence of 
under-ice blooms across the entire Arctic. However, we note that these blooms are impossible to view from the surface and particularly via satellite observations. Therefore, we need to look towards underice measurements that are currently lacking with respect to phytoplankton. Beyond dedicated field studies, the addition of biologically relevant sensors (e.g. transmitted light sensors and in vivo chl a fluorometers) to Arctic buoys, moorings, and automated underwater vehicles deployed under the sea ice could greatly assist in meeting the requirement for future under-ice observations.

Acknowledgements. Postdoctoral fellowship support was provided from the Fonds québécois de la recherche sur la nature et les technologies to C.J.M. Field support for the project was provided by the Polar Continental Shelf Program of Natural Resources Canada and through Individual and Northern Research Supplement Discovery grants from the Natural Sciences and Engineering Research Council of Canada to C.J.M., M.G., Y.G., M.L., D.G.B., and T.N.P. Additional support was provided by Fisheries and Oceans Canada (DFO) and the Canadian International Polar Year federal program. Special thanks are extended to J. Ferland, C. Brouard, K. Swystun, P. Rioux, G. Desmeules, and P. Guillot for logistical and data processing assistance, to L. Miller for helpful suggestions on an earlier version of the paper, and to the 4 anonymous reviews that greatly improved the paper. This is a contribution to the research programs of the Canada Excellence Research Chair unit at the University of Manitoba, ArcticNet, CEOS, ISMER, Québec-Océan, and DFO. We dedicate this paper to the memory of Martin 'Marty' Bergmann; his help and advice were precious during the implementation of the Arctic-ICE project.

\section{LITERATURE CITED}

Apollonio S, Matrai P (2011) Marine primary production in the Canadian Arctic, 1956, 1961-1963. Polar Biol 34: 767-774

Arrigo KR, Perovich DK, Pickart RS, Brown ZW and others (2012) Massive phytoplankton blooms under Arctic sea ice. Science 336:1408

> Bélanger S, Ehn J, Babin M (2007) Impact of sea ice on the retrieval of water-leaving reflectance, chlorophyll a concentration and inherent optical properties from satellite ocean color data. Remote Sens Environ 111:51-68

Comiso JC, Parkinson CL, Gersten R, Stock L (2008) Accelerated decline in the Arctic sea ice cover. Geophys Res Lett 35:L01703, doi:10.1029/2007GL031972

Cota GF, Anning JL, Harris LR, Harrison WG, Smith REH (1990) Impact of ice algae on inorganic nutrients in seawater and sea ice in Barrow Strait, NWT, Canada, during spring. Can J Fish Aquat Sci 47:1402-1415

Ehn JK, Mundy CJ (2013) Assessment of light absorption within highly scattering bottom sea ice from under-ice light measurements: implications for Arctic ice algae primary production. Limnol Oceanogr 58:893-902

Ehn JK, Mundy CJ, Barber DG, Hop H, Rossnagel A, Stewart J (2011) Impact of horizontal spreading on light propagation in melt pond covered seasonal sea ice in the
Canadian Arctic. J Geophys Res 116:C00G02, doi:10. 1029/2010JC006908

English TS (1961) Some biological observations in the central North Polar Sea Drift Station Alpha, 1957-1958. Arctic Institute of North America, Research Paper 13:1-80

Fortier M, Fortier L, Michel C, Legendre L (2002) Climatic and biological forcing of the vertical flux of biogenic particles under seasonal Arctic sea ice. Mar Ecol Prog Ser 225:1-16

Fukuchi M, Watanabe K, Tanimura A, Hoshiai T, Sasaki H, Satoh H, Yamaguchi Y (1989) A phytoplankton bloom under sea ice recorded with a moored system in Lagoon Saroma Ko, Hokkaido, Japan. Proc NIPR Symp Polar Biol 2:9-15

Galley RJ, Else BGT, Howell SEL, Lukovich JV, Barber DG (2012) Landfast sea ice conditions in the Canadian Arctic: 1983-2009. Arctic 65:133-144

> Garrison DL, Buck KR (1986) Organism losses during ice melting: a serious bias in sea ice community studies. Polar Biol 6:237-239

Gordon HR (1989) Can the Lambert-Beer law be applied to the diffuse attenuation coefficient of ocean water? Limnol Oceanogr 34:1389-1409

Grasshoff K, Kremling K, Ehrhardt M (1999) Methods of seawater analysis, 3rd edn. Wiley-VCH, New York, NY

Holm-Hansen O, Lorenzen CJ, Holmes RW, Strickland JD (1965) Fluorometric determination of chlorophyll. J Cons Int Explor Mer 30:3-15

Juhl AR, Krembs C (2010) Effects of snow removal and algal photoacclimation on growth and export of ice algae. Polar Biol 33:1057-1065

Leu E, Søreide JE, Hessen DO, Falk-Petersen S, Berge J (2011) Consequences of changing sea-ice cover for primary and secondary producers in the European Arctic shelf seas: timing, quantity, and quality. Prog Oceanogr 90:18-32

> Lovejoy C, Vincent WF, Bonilla S, Roy S and others (2007) Distribution, phylogeny, and growth of cold-adapted picoprasinophytes in Arctic seas. J Phycol 43:78-89

> Lund JWG, Kipling C, Le Cren ED (1958) The inverted microscope method of estimating algal number and the statistical basis of estimations by counting. Hydrobiologia 11:143-170

Mann KH, Lazier JRN (1991) Dynamics of marine ecosystems. Blackwell Scientific Publications, Oxford

> Marsden RF, Paquet R, Ingram RG (1994) Currents under land-fast ice in the Canadian Arctic Archipelago Part 1: Vertical velocities. J Mar Res 52:1017-1036

Melling H (2002) Sea ice of the northern Canadian Arctic Archipelago. J Geophys Res 107:3181, doi:10.1029/ 2001JC001102

Michel C, Legendre L, Therriault JC, Demers S, Vandevelde $T$ (1993) Springtime coupling between ice algal and phytoplankton assemblages in southeastern Hudson Bay, Canadian Arctic. Polar Biol 13:441-449

> Michel C, Ingram RG, Harris LR (2006) Variability in oceanographic and ecological processes in the Canadian Arctic Archipelago. Prog Oceanogr 71:379-401

Mundy CJ, Gosselin M, Ehn J, Gratton Y and others (2009) Contribution of under-ice primary production to an iceedge upwelling phytoplankton bloom in the Canadian Beaufort Sea. Geophys Res Lett 36:L17601, doi:10.1029/ 2009GL038837

Mundy CJ, Barber DG, Michel C (2005) Variability of snow and ice thermal, physical and optical properties perti- 
nent to sea ice algae biomass during spring. J Mar Syst 58:107-120

Mundy CJ, Ehn JK, Barber DG, Michel C (2007) Influence of snow cover and algae on the spectral dependence of transmitted irradiance through Arctic landfast firstyear sea ice. J Geophys Res 112:C03007, doi:10.1029/ 2006JC003683

Nicolaus M, Katlein C, Maslanik J, Hendricks S (2012) Changes in Arctic sea ice result in increasing light transmittance and absorption. Geophys Res Lett 39:L24501, doi:10.1029/2012GL053738

Parsons TR, Maita Y, Lali CM (1984) A manual of chemical and biological methods for seawater analysis. Pergamon Press, Toronto

> Pawlowicz R, Beardsley B, Lentz S (2002) Classical tidal harmonic analysis including error estimates in MATLAB using T_TIDE. Comput Geosci 28:929-937

Perovich DK, Jones KF, Light B, Eicken H, Markus $\mathrm{T}$, Stroeve J, Lindsay R (2011) Solar partitioning in a changing Arctic sea-ice cover. Ann Glaciol 52:192-196

Perrette M, Yool A, Quartly GD, Popova EE (2011) Nearubiquity of ice-edge blooms in the Arctic. Biogeosciences 8:515-524

Polashenski C, Perovich DK, Courville Z (2012) The mechanisms of sea ice melt pond formation and evolution. J Geophys Res 117:C01001, doi:10.1029/2011JC007231

Riebesell U (1989) Comparison of sinking and sedimentation rate measurements in a diatom winter/spring bloom. Mar

Editorial responsibility: Graham Savidge, Portaferry, UK
Ecol Prog Ser 54:109-119

Sakshaug E, Skjoldal HR (1989) Life at the ice edge. Ambio 18:60-67

Schlitzer R (2006) Ocean data view. Alfred Wegener Institute for Polar and Marine Research, Bremerhaven. Available at http://odv.awi.de

> Sherr EB, Sherr BF, Hartz AJ (2009) Microzooplankton grazing impact in the western Arctic Ocean. Deep-Sea Res II 56:1264-1273

Smith WO, Codispoti LA, Nelson DM, Manley T, Buskey EJ, Niebauer HJ, Cota GF (1991) Importance of Phaeocystis blooms in the high-latitude ocean carbon cycle. Nature 352:514-516

Strass VH, Nöthig EM (1996) Seasonal shifts in ice edge phytoplankton blooms in the Barents Sea related to the water column stability. Polar Biol 16:409-422

> Stroeve J, Markus T, Meier WN, Miller J (2006) Recent changes in the Arctic melt season. Ann Glaciol 44:367-374

Sverdrup H (1953) On conditions for the vernal blooming of phytoplankton. J Cons Int Explor Mer 18:287-295

Taylor JR, Ferrari R (2011) Shutdown of turbulent convection as a new criterion for the onset of spring phytoplankton blooms. Limnol Oceanogr 56:2293-2307

Tremblay JÉ, Simpson K, Martin J, Miller L, Gratton Y, Barber D, Price NM (2008) Vertical stability and the annual dynamics of nutrients and chlorophyll fluorescence in the coastal, southeast Beaufort Sea. J Geophys Res 113: C07S90, doi:10.1029/2007JC004547

Submitted: March 25, 2013; Accepted: October 4, 2013

Proofs received from author(s): January 6, 2014 